\title{
Youths' Educational Resilience in Rurban Jumla: A Narrative Inquiry
}

\author{
Suresh Gautam* \\ School of Education, Kathmandu University, Lalitpur, Nepal
}

\begin{abstract}
Drawing on the concept of resilience, this paper discusses a narrativebased research which explores rural/urban disparities among young people who face various obstacles to continue their higher education in recently announced 'urban' Jumla. I explore major adversities faced by the youths in rural-urban disparities, their promotive and protective measures, and cultural and family assets to cope with adversities. The three narratives illustrate how the youths develop their assets to overcome geographical and social adversities in rural-urban disparities. In doing so, I mainly deal with the youths' issues of higher education attainment. They experience that it has been more privileged living in urban than in rural areas to continue their higher education. However, they could not detach themselves from the rural values and tradition. I generate meaning of youths' educational resilience that overcomes such rural urban disparities.
\end{abstract}

Keywords: youths, adversities, educational resilience

\section{Orientation: Rurban Dynamics in Jumla}

The year 2014 was remarkable for urban development in Nepal as 72 municipalities had been added, albeit without proper infrastructure development. A council of municipality had recently been formed - Chandan Nath Municipality - in Jumla. Jumla is one of the Himalayan districts in the Mid-Western Development Region in Nepal. The altitude of Jumla varies from 915 meters to 4769 meters. Jumla is linked with road transportation from Surkhet, where the distance covers 232 Kilometers, and air transportation from Kathmandu, 
Surkhet and Nepalgunj. I use the concept of rurban to refer that everyday life of Jumli (people who are living in Jumla) has been affected by both rural and urban lifestyles. Mostly, rural urban dynamics have been embedded among the Jumli youths but they are facing adversities of rurban context of Jumla. At the same time they are becoming resilient to peruse higher education.

There is a campus affiliated to Tribuvan University ${ }^{1}$ for higher education in Jumla. It has got three streams of study in the undergraduate level, namely, humanities, education and management. It has also got the approval for running the Master of Education programme. Yet, most of the well-to-do people in Jumla move to the cities like Surkhet, Nepalgunj and Kathmandu (Surkhet and Nepalgunj are the cities in the Terai nearer to Jumla. Kathmandu is the capital city of Nepal) for further education. Those who cannot afford their higher education in cities like Kathmandu, Surkhet and Nepalgunj, mostly get admitted at Jumla Multiple Campus. I chose those students who were studying undergraduate at Jumla Multiple Campus as the research participants for this study. By doing so, I could observe their educational resilience in R-Urban Jumla.

During my stay, I experienced that Jumla is a growing urban hub in the Western hill and mountain region of Nepal. Many villages from three Village Development Committees (VDCs) (i.e. from Kartik Swami, Chandan Nath and Mahat) have been merged to make Chandan Nath Municipality. I sensed that it is also growing as an educational center for the students of upper and lower mountain regions in Western Nepal. Some of the vernaculars in Jumla Bazaar have been replaced by concrete buildings, Ramsi-a local rice-was being replaced by the imported rice, menus of some hotels have drastically been changed, mostly by adding 'global' food items such as Momo and Chowmin ${ }^{2}$. Some schools have started using English as a medium of instruction. Rural Jumla has been gradually urbanized; however, I observe rural dynamics in terms of buildings, food habits, education and life styles of people. In this sense, I used the concept of R-urban to describe the transition of society from rural to urban. Such transition makes most of the youths move to bigger cities to get higher education but they hardly get such opportunity to move to bigger cities for their study. They have been facing various adversities in the villages of Jumla but at the same time they have developed their assets to continue their higher education. In this line, my purpose in this research is to portray how these youths in Jumla develop educational resilience to complete their higher education.

There is an opportunity for the students to get higher education as one of the colleges of Tribhuvan University is located there. However, the college 
lacks resources such as library and faculties. Likewise, irregular classes due to weather hardship, faculties' intention and students' (de)motivation appear as major adversities. In contrary to that, students expect to get almost all educational facilities in Jumla which they may get in cities like Nepalgunj (Nepalgunj is closely connected to Jumla both economically and geographically) and Kathmandu if they could afford their stay in those cities. However, they could not go to cities to pursue higher education because of their family and social obligations.

I was in Jumla for carrying out a research study on Early Grade Reading Assessment (EGRA) of the students. There were nearly twelve undergraduate youths who were working as enumerators in our research team. I accompanied six of them to monitor their activities. During my stay, I was inquisitive about knowing the holistic educational scenario of Jumla since it was tagged as the 'most remote and undeveloped part of Nepal'. Thus I started exploring the situation of higher education in Jumla. In doing so, I selected four participants out of six who were working with me for ten days. They were studying at the Bachelor level at Jumla College. They were around 22-25 years old and they were facing various adversities to continue undergraduate education in Jumla. I chose undergraduates who were struggling to pursue their education in Jumla for two reasons: first, I was searching educational resilience of such youths in Kathmandu for my $\mathrm{PhD}$ project; second, I was interested to see such educational resilience of the youths in R-urban context like Jumla.

Educational resilience for me is the personal capacity, interpersonal interaction, and community and their engagement that influence the process of coping with challenges in adverse contexts of getting higher education (Liborio \& Ungar, 2013, pp. 2-3). The youths in Jumla have some personal and interpersonal assets to continue their education in their community. Here, Ungar's

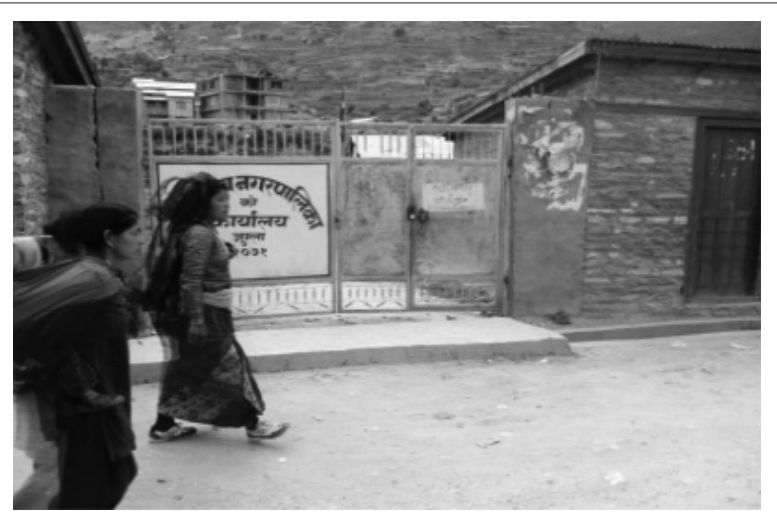

Figure 1. People walking by themunicipality office, Jumla. (2011) opinion is useful to discuss the educational resilience of youths from constructionist approach. Ungar (2004) writes "a constructionist interpretation 
of resilience reflects a postmodern understanding of the construct that better accounts for cultural and contextual differences in how resilience is expressed by individuals, families, and communities" (p. 341). Thus, educational resilience is a complex process for us to identify the complex chain of economic, cultural and social barriers that lead to a process of, or capacity for, or the outcome of successful adaptation despite challenging and threatening circumstances (Garmezy \& Masten, 1992). It is insightful for me to observe the educational resilience of urban youths in Jumla.

\section{My Arrival to Urbanized Jumla}

It was summer. I landed in Jumla by Tara air. It was difficult for me to carry my luggage to the hotel where I stayed. I did not see any porter around the airport. There was no chance to hire any taxi and other vehicle either. I was feeling that people were gazing at me when I stepped down to the market. At the gate of airport there was a hoarding board that was welcoming me in Jumla. Possibly, the hoarding board symbolized that it was urbanizing. I was walking with heavy luggage, passing by Kala Kholi, Karkiwada, Tudikhel, and arrived in the hotel that was booked for me for the following ten days. My new friends with whom I was going to work were waiting for me at the hotel. I was there for 10 days to collect some baseline data for one of the NGOs in Kathmandu. I was unknown to these new friends. I took a chair and sat near them. One of the NGO staff introduced me with my new friends. There were altogether 12 friends working as data enumerators. I introduced myself again. I was planning to work closely with a group of four new friends. They all were undergraduates studying Bachelor in Education (BEd) at Jumla Campus. Two of them were waiting for the results of BEd third year. I was interested in them as I was working with the youths, especially urban youths, and about their resilience. I liked to choose four out of those six as my research participants.

In the afternoon, they were planning to have Khaja ${ }^{3}$. When I got a menu I saw the list of Momo, Chowmein, and egg-roll. The menu was not different from the menu of the restaurants in Kathmandu. We ordered Momo for Khaja. We all enjoyed Momo in Jumla. Some of the friends had 'Coca-Cola' as well. I thought that Jumla is highly urbanized in terms of food habits of people. I was then interested to know about the cultural heritages, geographical topology and geographical heritages of Jumla. My participants were narrating the cultural, religious and famous geographical locations of Jumla. My eagerness to know about the youths and their everyday life was growing. Then after, we went for an evening walk around Chandan Nath Municipality. We saw nearly four institutional schools, many cafes and restaurants, and two commercial banks in or near the 
bazaar. When we returned to the hotel, dinner (Sanjhako Khana) was ready. The dinner was not different from the one in Kathmandu: a plate of rice, a bowl of cereal, another bowl of cauliflower curry, a mini-plate of tomato pickle. We saw some of the guests were enjoying Tuborg and Carlsberg beer there. I saw imported whisky and rum decorated in the showcase of the hotel. I was ensured that Jumla was no longer a village.

On the other hand, most of the students were (are) likely to go to urban centers like Surkhet and Nepalgunj to study. Some local elites have already migrated to the southern part of Jumla: Surkhet, Nepalgunj whereas the ultra-elites have a choice to migrate to Kathmandu. Still, many students are pursuing their higher education in Jumla. In this line, they mainly faced social risks and adversities to study in Jumla as it lacks many educational opportunities in

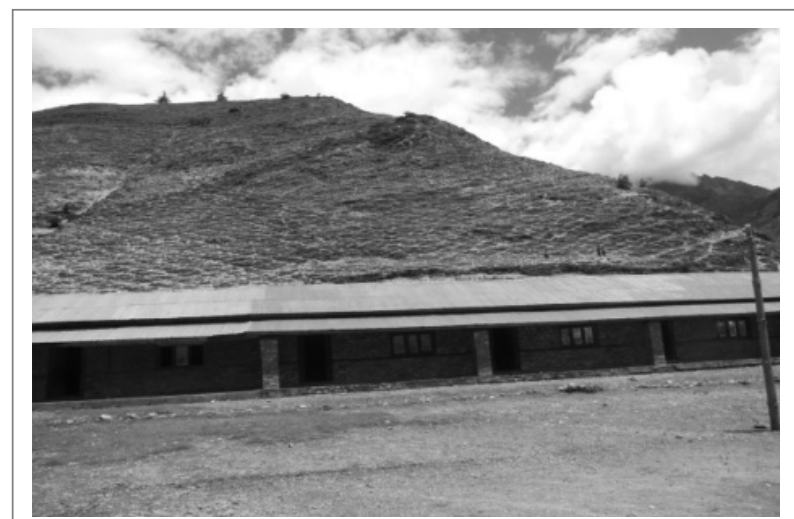

Figure 2. A school in Jumla. comparison with the cities. Students are facing various complexities created by urban life styles, and they are adopting resilience as a result. I have attempted to examine the tensions between that vulnerability and resilience as characteristics of R-Urban Jumla via three narratives. These three narratives can be arranged into the three specific regional classifications of Jumla. As I was working with the people who were from the various village development committees, I asked them about the features of their village; I explored a unique thread linking their narratives. Historically, Jumla has its local classification of places categorized as Chaudhabise, Panchsau, Asi and literally mean the numbers those refer to 1420, 500,80 respectively). These three constructs represent three different societies rather than geographical regions. These numbers are allocated to identify the location so that Jimbal ${ }^{4}$ could collect tax from the local people. However, the local people interpret these construct differently. Chaudhabise (1420) usually refers to the area where people grow millet and potato; the people there do not have an easy access to and facilities of 'cities', they have less political affiliation and would like to be the part of panchsau (500) and asi (80). Similarly, 500 is supposed to be more 'advanced' and 'developed' than 1420 because the geographical structure in 500 is comparatively easier. They have more cultivable farms and they easily get access to 
94 S. Gautam

the market. Similarly, 80 is the plain area located near/around the market, thus it is considered the most developed area in Jumla. People from 500 and 1420 were often discriminated on the basis of their geographical basis.

\section{Research Methodology: Narrative Inquiry}

As I reached Jumla I heard the stories of my participants. Their stories helped me understand the geo-physical complexities of getting higher education in Jumla. At this time, I realized that stories were not just told for the sake of telling "they are blended with human existence for survival” (Webster \& Mertova, 2007, p. 1). However, I was aware of cultural context, my position as a researcher and narrative sensibility (Trahar, 2008b). As a researcher, I brought my reflection of my participants and their memorable which uncover layers of understandings about youths and their culture and how they have anticipated change in Jumla.

In this paper, I collected the stories of my four participants from three different regions. I chose four participants from three geographical and societal regions who were all undergraduates-studying Bachelor of Education (B. Ed.). The first participant Bhim Bahadur (pseudonym) who mostly inhabited in 1420 was struggling to complete his B. Ed. from Jumla Multiple Campus. Similarly, the second participant Jit Bahadur (pseudonym) was living in 500 and would like to have a house in 80 . Two more participants Shanti Maya and Mina Kumari were living in 80 who expected to settle down in Nepalgunj and Surkhet respectively.

In the beginning of selecting my participants, I was not aware of these local constructs of 1420,500 and 80 . I traced out the pattern of these local ways of classifying people in Jumla via informal conversation. I organized and reflected their educational resilience via informal conversation, reflective notes and journal entries made during the 10 days I spent with them. In this line, I am locating space for "interactive voice, one that reflects the intersubjectivity between their voice and the narrator's voice" (Trahar, 2008a, p. 261). I was engaged in informal conversion as a collaborative activity to collect field notes (Trahar, 2008a, p. 260).

In this regard, I employed narrative inquiry to depict the understanding of the youths in Jumla through "collaboration between researcher and participants, over time, in a place or series of places, and in social interaction with milieus" (Clandinin \& Connelly, 2000, p. 20). Thus, the research process was developed as the flow of stories. During the meaning making process, I was consistent in questioning them, their stories, and myself while writing their experience along with my reflection. In doing so I never forgot to connect the dots around the center of youths and their educational resilience. 


\section{Story 1: From Chaudhabise (1420)}

"What to do sir, I didn't get a chance to go to Surkhet or Nepalgunj for my further study when I completed 0+2 from Chandan Nath Higher Secondary School but I could not. I am a B. Ed. Second year student," one of the participants sighed and showed his interests to go to some cities for further education. Like my participant I also had a dream to go to Kathmandu for further education. Possibly, I had imagined the city would give me more than my village. I was never sure what the city would give me, but I was infatuated by the glamorous life-style of the city. I do not understand why these cities attract more students? The story continues.

He said that he got married when he was in grade eight. It was an arranged marriage; he could not choose his spouse himself. His parents decided who their son would marry. He got married believing that his spouse would help him to complete all household chores so that he could continue his education. He carried out his study further and he would also like to send his spouse to school at grade seven. However, it was not possible in the rural society. His parents did not like to send their daughter-in-law to school. It was very difficult time for him. He had a dream to have an educated wife who would find a job and work in an office. But it was not as easy as he had thought.

After his marriage, his responsibilities increased. His wife was also a seventh grade student and he thought to help her continue her education. It took him two years to convince his parents about sending his wife to school. "Sir, it was the toughest time to convince my parents to allow my wife to go to school." He taught his wife night after night. She prepared herself to appear the SLC (School Leaving Certificate) examination. "It was not an easy job to send my wife to school in the village. If my family and parents saw me sending my wife and helping her they would call me JOITINGRE. She had many responsibilities to accomplish at home."

Listening to my participants, I recalled my childhood. I was brought up in a village of Surkhet district in the Mid-Western Development Region, where husbands were not supposed to work in the kitchen and field. They hardly sent their daughters and daughters-in-law to school. Even my friends in school studying at grade IX and $\mathrm{X}$ were married. We were around 30 students in grade $\mathrm{X}$ and about 10 boys had already got married.

I sensed that early marriage was one of the adversities in the villages. When they got married, possibly, they had more responsibilities, including having to do 
the household chores. Within a couple of years they became father and mother and could not continue their education.

He further continued, "If I assisted her with work, my family and villagers would not tolerate. She is supposed to accomplish all her tasks by herself. It is our culture that female members should do all the work at home themselves. I could not help her openly as I am a male since males are not supposed to help females especially wife in the family and community."

Now he is a father of two sons. One of his sons was four years old and the other was six months old. He was studying at Jumla Multiple Campus. It would take him nearly two hours to reach the campus from his house and he usually felt frustrated when teachers remained absent. While walking to college, he would feel physically tired and during the lessons, he was

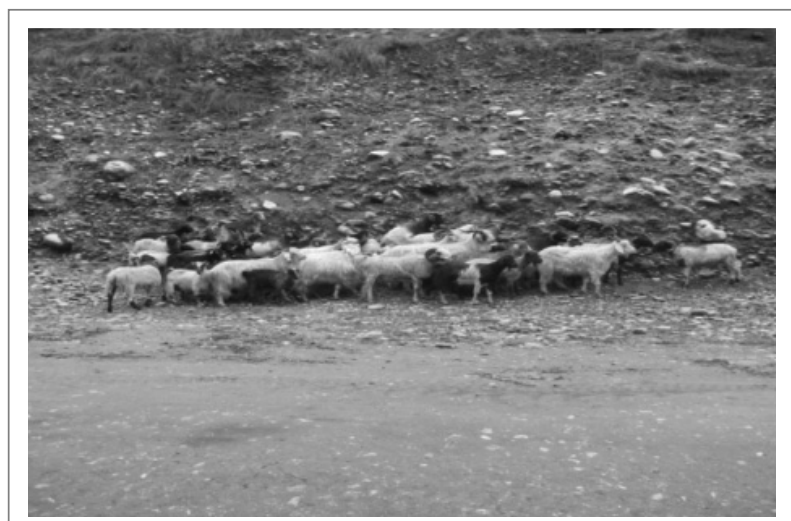

Figure 3. Sheep grazing in the field. possibly haunted by the works that remained for him at home. These made it difficult for him to understand what his teachers taught in the classrooms.

He usually got up early in the morning at around 3:00 am. He completed a few tasks such as caring for the cattle. He usually took out his cattle from cattle shelter and gave fodder, prepared a few breads so that he could eat in the college. He attended classes and went home back and had lunch at around $1 \mathrm{pm}$ and started working in the field. Mostly he ploughed the field and cultivated potatoes. He did not have much work in winter as the field was covered by snow-crops are produced in only one season in Jumla. He sent his four- year old son to the private school in Urthu Chautara.

"I fought with my family and convinced my parents to send my wife to school. My parents were not happy about their daughter-in-law's going to school. I was in a dilemma whether to support my family's view or my own view to send my wife to school." He smiled and continued. After collecting firewood and fodder in the morning she cooked food and prepared herself to go to school. She studied in school during the whole afternoon but she could not be regular whereas her husband was regularly continuing his education in the higher secondary level. 
Anyway, both husband and wife were working together and studying together. During those days they became happy as she passed the SLC. "It was the most glorious moment in my life", he said with a smiling face.

"The turning point of my life was when I became a father. I felt more responsibilities towards my family and that put a lot of pressures upon my education", he said. The birth of the first son brings happiness in the family but he was feeling that it increased his responsibility. Therefore, they could not leave their family and migrate to the urban areas.

I am often thinking to leave this village and to go to urban areas such as Nepalgunj and Surkhet, but it is not possible for me as my parents need my support. My parents are growing older and I feel I need to support them as they cannot work any longer. We produce potatoes and corn but these productions are not sufficient to feed the family members. During the two years of my study of higher secondary education my mother worked as a labourer and spent on my education. I was really difficult then to afford my education. I could not leave my family alone as they thought I was the only one who had to take care of them. After completing my higher secondary level I started working in a Kathmandu based NGO. It was a great relief for me at that time. But the job did not last very long. When I remained absent at work for a few days during the examination, they kicked me out of their office. I was tortured more because I was blamed as Jumli, as incompetent, as dishonest. I swear sir, I worked wholeheartedly as far as my skills and knowledge supported. I could not think of living as a corpse then I left the job. On that very day I decided to get into civil service but not to work in any NGO.

\section{Cultural Assets and Educational Resilience}

I ask myself why a certain participant likes to migrate to Nepalgunj and Surkhet but he does not actually do? What does he think about his parents? How was he able to continue his and his wife's education even in Jumla? Such questions raise the coping strategies of the participants against adversities. Possibly, the youths are constructing their opinion, beliefs from their community and family as assets to cope with the adversities. Jit Bahadur has been experiencing various adversities in 1420 . He has been struggling to cultivate crop in steep land and grow maize, millet and potatoes to feed his family. There is not any land where they can cultivate rice. Thus, they are called from 1420. At the 
same time people in 1420 are excluded and underestimated by other regions as they are far behind from the urbanized infrastructure such as market, hospital, and school.

In the above narration, the participant is struggling for maintaining his livelihood in rural areas. He has a dilemma to choose urban ways of living

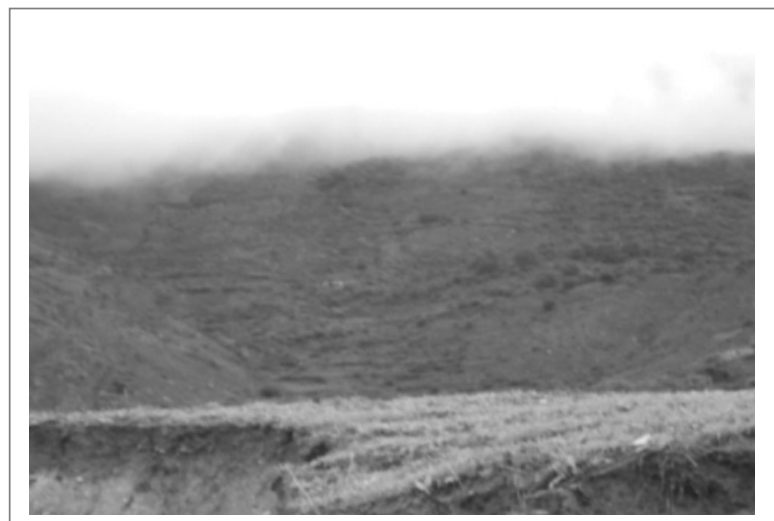

Figure 4. Land topography of 1420. with good job in an office and a company like in the urban center. He could not completely detach from the rural dynamics of his livelihood, such as to maintain the traditional ways of farming and cultivating land and caring his parents, but he expects to be and to do something in urban areas. The case of the participant shows that he has developed a certain kind of resilience in his cultural context.

The participants have developed certain protective and promotive abilities to continue their higher education in Jumla. They overcome adversities created by the r-urban construct. First, the presence of protective factors is family. Family always encouraged them to go ahead in their life (Story 1). However, they resisted traditional family values and felt the need of higher education to get better job and life (Story 1). There are several adversities such as early marriage, discrimination between to sons and daughters or deep rooted belief that daughters should not be sent to school (Story 1). These adversities come up with the rural belief systems where daughters were engaged in household chores. When these youths go to school and learn some promotive factors to continue their education, their teachers suggested to them to get higher education. They can get better job if they are educated. When such temptation is increasing, they like to settle themselves in urban centers where they can buy all facilities.

\section{Story 2: From Panchsau (500)}

In this narrative, the participant is the one with sound income to have a house in Jumla Bazaar, who can afford noodles as the afternoon lunch, who can send children to a private school, who owns a motorbike, who can have a touch-screencell-phone, who could afford jeans and t-shirts for his spouse.

I went to Dolpo to collect mushroom ${ }^{6}$, so that I could earn money, 
continue education and build a house in 80. I heard many successful stories of mushroom collection and I dreamed to be a rich man with a house in Jumla, especially in 80. My house was located in 500 but I liked to have a house near the bazaar with all facilities. My father was

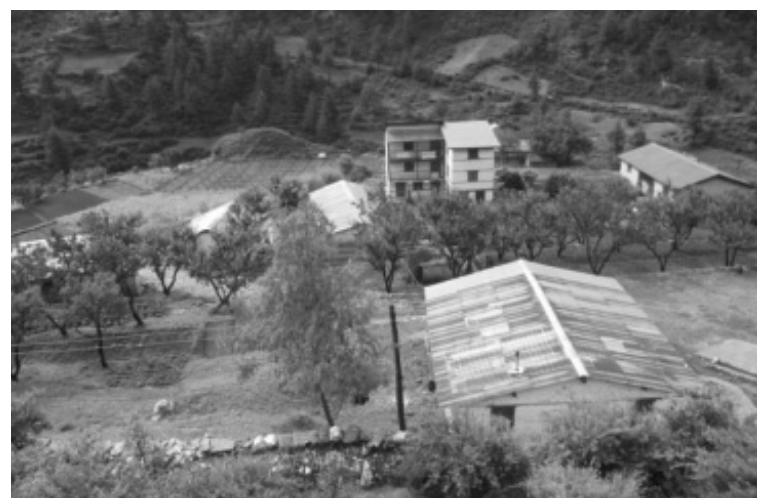

Figure 5. Land topography of 500. a farmer and we had a patch of land where we could produce millet and rice (local rice) but that were not enough for us to live on for the whole year. We usually did not have work and we drank raksi and played cards to pass time. People in 80 were supposed to be rich as they had got paddy and thus could earn more. They also had access to the goods in Nepalgunj and Surkhet. Moreover, they were called civilized. My parents and siblings were living in Grajyankot known as 500 but I didn't like their tradition so that I rected a room in Khalanga, Chandannath Village and lived alone. My parents forced me to get married but I didn't. I had promised I would not get married unless and until I had a home in 80. I liked to live in urban center with facilities. But I did not have any earnings, no money and no work. I even went to Nepalgunj and Surkhet thinking that I could get both education and money. It was not so easy to live there and to earn money. Many people narrated stories of mushroom collection, which I knew was a way to be rich in a short span of time. It was not possible with jobs, or with animal husbandry or farming in the village.

Last year I went for mushroom collection when I walked three days with food and clothes, and reached the remote snow-land. I could not collect more but only 150 pieces. I could earn just NPR (Nepali currency) 150,000. I was thinking of earning more money at any cost but I could possibly have to murder anyone to be rich.

There was a higher secondary school near my village but I went to the school in 80 (place). I felt myself to be esteemed as I studied in 80. I liked to move around the cities such as Nepalgunj, Surkhet and 
Kathmandu during holidays. As I reached 23, I have not got married yet because I like to establish myself as an urban youth. I can have jeans, $t$-shirt, sport shoes, goggles and will be civilized and modern. I listen to Hindi songs more than Nepali and Deuda. I spent most of the time by travelling to cities that affected my education. My ultimate destiny is to earn money and make a house in 80. I don't think that studying at Jumla Multiple Campus makes me competent. As people who studied in Kathmandu and Nepalgunj have better facilities and services, they have good network and education that helps them to get jobs easily. My parents could not afford my education in those cities of Nepal; I attempted to go there but failed as I had not any other sources. If I cannot make anything solid in Jumla, there is no worth of living here.

When I was in my village as a boy during the $90 \mathrm{~s}$, I also liked to listen to Hindi songs and get education in an institutional (private/boarding) school. I was studying in a public school and completed my school education from the public school. My home was located near the Bazaar; my friends were from the same Bazaar area. I felt proud to live in the Bazaar, however, I felt inferior among the friends who went to institutional schools. I sensed similar experience of my participants as well. How do rural and urban ways of living create the sense of superiority and inferiority? I wonder why people consider living in rural areas as being backward. How did I learn such disparities created by rural and urban locations? Nevertheless, my participants are resilient to cope with adversities created by R-urban disparities.

\section{Youths' Educational Expectation: Be Urbanized}

The above stories of the participants helped me understand the expectation of the youths who like to be more educated and urbanized. They are expecting that education may increase their economic strength and set themselves in urbanized places. In rural Jumla, 500 is a geographical terrain where people have mixed kinds of productions. They have little rice cultivable land and more steep land where they can cultivate millet and potatoes. They have less productivity than 80 s but more than 1420 . The youths in 500 feel esteemed but they have a wish to make a house and own some properties in 80 or in Nepalgunj and Surkhet. However, they are searching jobs mostly in the NGOs and INGOs that are mushrooming in Jumla. They also intend to get jobs in civil service but they are afraid of huge competition in the civil service. They choose an easy way to get a job in the NGOs and INGOs in Jumla. They do not dare to leave Jumla because 
they might not have as comfortable a lifestyle elsewhere as they have it in Jumla. "I am preparing for civil service, let's see when happens." Most of my friends who were enrolled in schools could not continue their study and thus went to India to earn money. Still most of the students go to collect Yarcha during the school going time and go to the Terai (Nepalgunj and Surkhet) during the hot season. The students' dropout has not been eradicated here yet. It shows that very few students can continue their higher education in Jumla. Those students who continue their education at Jumla Campus have less frequent attendance, less focus on their education as they are facing other problems such as irregular classes, lack of qualified teachers, etc. Despite facing various adversities in their higher education they are competing in the civil service commission (civil service commission is an autonomous body of selecting officials in government offices). There is a faith in and charm of civil service in Jumla.

In this terrain, most of the youths have been developing "cognitive engagement" (Reyes, 2013) so they are expecting to get into the civil service. As Story 2 indicates, the participants recognized the value of living in an urban center does not mean to be detached from the parents and neighborhood but it may create a thread to link rural and urban regions. I feel that the youths in 500 feel empowered because of the services they have in their society. They can get easier access to education and health facilities as compared to 1420. They have been seeking their identity as Jumli and would like to stay in Jumla with all the facilities they get in urban centers like Nepalgunj and Surkhet. The youths are more concerned about their identity that is associated with the space where they live as an "emotional engagement" (Rayes, 2013). However, these youths possibly devoted themselves to having a proactive, connected and committed engagement.

\section{Story 3: From Asi (80)}

The final two participants were from 80 - a fertile land where they have irrigation facilities and they can cultivate more rice than in 1420 and 500. They have stoned storied houses in and near the marketplace. They have easy access to schools, hospitals and the market. Many see themselves as superior because they can feed themselves

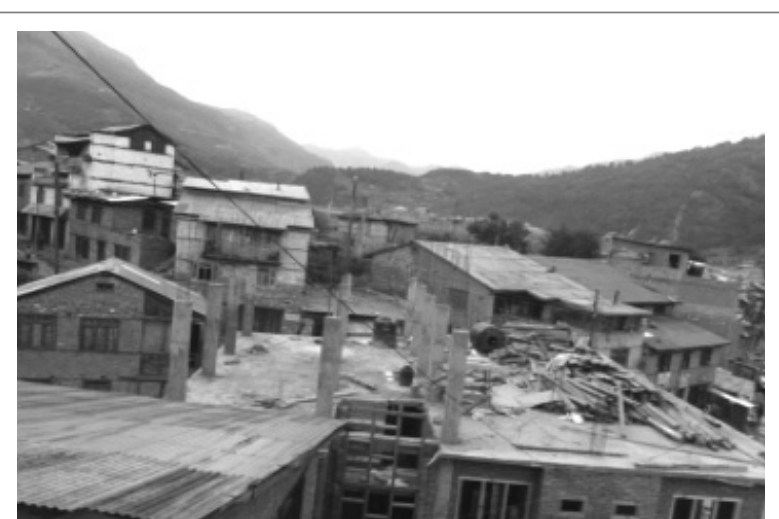

Figure 6. Housing in 80. 
102 S. Gautam

with rice without importing it from Nepalgunj and Kathmandu. Asi is the center for all development activities as schools and a college were set up in 80 at first so that most of the people in 80 got a chance to study. Most of the developmental organizations have launched their programmes in/near 80 as it is easily accessible for them. They can have more facilities and more human resource so that they think that they are superior.

I went to Surkhet with my brother to continue my education in Surkhet. We have a home and some land in Surkhet. I and my brother were at the same grade in a school of Surkhet.

The school administrators refused to take our admission at first as we were migrated from Jumla. They thought that students from Jumla could not have good performance in their education. We were good at study, my brother always stood first and I was in the second position. The teachers at the new school underestimated us as we were from Jumla, as if Jumla is an uninhabited land where only savages live. I was too young to convince them that all Aryan civilization was spread from Jumla. I was always sitting on the last bench with other girls at the new school. I spoke a different dialect and they ridiculed me. I did not feel comfortable at school. It was tough for me to speak like them and to learn like them. Thus, I left Surkhet and came back to Jumla. However, my brother continued his education there.

As I came back to Jumla, local people of Jumla appreciated me as I had studied (at least for some time) in Surkhet- an urban center. They could have believed that I learnt many new things there, so that I could get the first position in the exam. All teachers loved me, not because I was good at study but because I came from Surkhet. It was strange for me to get such good responses from teachers. When I appeared the first term exam, my result was not good enough and they suspected of my abilities.

\section{Educational Resilience of Youths}

These three stories provide an imagery of the various adversities the participants faced in the rural-urban (r-urban) context of Jumla on the way to becoming educated. These all youths are searching their future in Jumla. In Story 1: 1420, the participant has clear vision to take care of his parents in their old age either by doing animal husbandry or by engaging in agriculture in an improved way. In Story 2: 500, the participant has a vision to start his own business very 
soon so that he would be nearer his parents and the third story creates an ample opportunity to get a job in any sector. In Story 3: 80, 2 participants have some kinds of social competences gained in the urban context so that they can solve everyday life problems. However, they developed resilience against the rural urban disparity with the clearer sense of personal autonomy, purpose and future.

Jumla and its development have been associated with the education that they need. Jumla has potentialities for animal husbandry, horticulture and production of herbs. The education system has not been able to address the need of the local people (District Education Office, 2010). It seems that imported education has taught them to eat rice, find jobs, and work for others. The schooling has been highly influenced by the urban schooling as Kathmandu has been spreading its philosophy. Participant from Story 1: 1420 does not like to leave this place as he likes to serve the needs of his parents who are gradually growing older. He could not migrate to the Terai region as he has to take care of his parents. He thinks it is important to take care of his parents. He is planning to have some technical knowledge on agriculture so that he could contribute to the family and society. Most of the youths who studied in Karnali Technical School reflect that the School has prepared students just to be job seekers. Therefore, education has not served the real interest of the local people. They develop their resilient culture to adjust themselves in Jumla. This idea of resilience is more focused on the individual performance. The term not only indicates the positive efforts of an individual to resist against the risks, but I have used the term in broader perspectives to also deal with social and cultural struggle to come up with the certain triumph.

These youths have experienced the ten years long people's war in Nepal and stood for peace and sustainability in Jumla. Their belief system itself is constructed on the basis of resilience to mitigate conflict(Reyes, 2013).In such circumstances, they believe that there are less risks of the conflict in urban than in rural settings. Jumla got affected by the ten years long armed conflict more because of its villages. I do not think so as many cities are burning in violence and war around the globe. Even in the context of Jumla, these youths have bitter experiences of war at

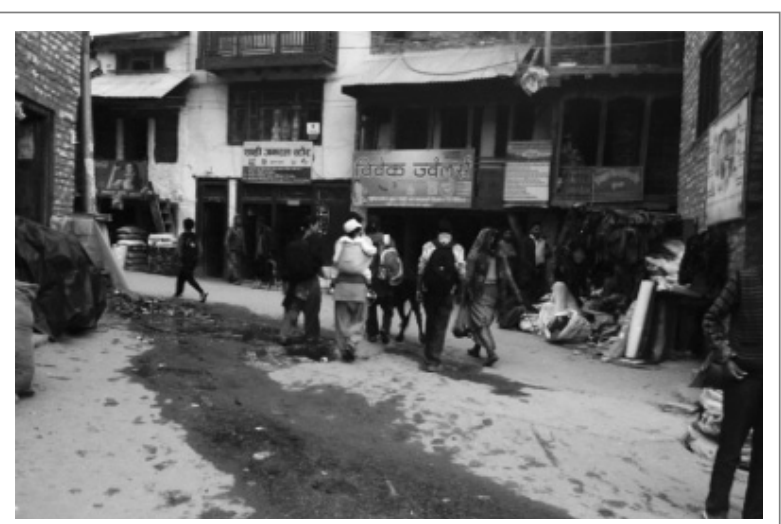

Figure 7. Urbanization in 80 . 
104 S. Gautam

Jumla bazaar as well.

It is a complex process for us to identify the complex chain of economic, cultural and social barriers in Jumla for the youths to be educated that may lead to "a process of, or capacity for, or the outcome of successful adaptation despite challenging and threatening circumstances" (Garmezy \& Masten, 1992). The Jumli youths are trying to develop their strengths to cope with the urbanized life styles with improved income level and education. They are even ready to get quality education paying a huge amount of money if available in Jumla.

These protective factors may vary in time and context. In this research we explore the internal protective factors as the personal and social characteristics of the youths and adolescents, such as activity level, disposition, responsiveness to people, social orientation, communication skills, ability to focus, self-concept, internal locus of control, and desire to improve themselves (Werner \& Smith, 1993). Likewise, we focus on external protective factors which are the sources of support and structure in the child's environment such as parental warmth, presence, informal sources of emotional support, peer relationships, rules in the household, shared values and access to services (Warner \& Smith, 1993).

The term promotive factors refer to the assets of the Jumli youths to combat with the adversities they are facing. It includes the importance of positive cognitive, emotional and behavioral skills in spite of the contexts of adversity. The Jumli youths seem to be developing their educational resilience such as 'optimism, tolerance, problem solving, sociability, flexibility' (Reyes, 2013).

\section{Re-Orientation}

Getting higher education in Jumla and the Jumli youths' educational resilience are two important aspects that this paper raised in the educational and urbanization context of Jumla. The students in Jumla are experiencing adverse situations resulting from poverty and deprivation but they seem strong enough to fight against such adversities with family values, entrepreneurship skills and services. Their educational achievement is one of the social and economic determinants of career growth. Most of the risks the youths in Jumla are taking have been created by the transformation in life styles brought about by rural/ urban transformation. The youths are tempted to adopt urban life styles. However, their income, education and livelihood do not allow them to do so. Thus, it may create many risks. Some of the risks are associated with the product of traditional society where early marriage, early parenthood are taken for granted. On the other hand, certain risks are related to the changing urbanized lifestyles. These youths 
are trapped between the transformations of these rural urban contexts. But at the same time they have prepared themselves to solve these problems on their own. Their resilience seems more in urban cultural context where they can continue their further education to compete in the civil service and build a house in the urbanized Jumla.

\section{Notes}

1 Tribhuvan University is the oldest and largest public university in Nepal. It has got sixty constituent campuses and more than a thousand affiliated colleges across the country.

2 Momo and Chowmein are quite popular Tibetian dishes found in the popular restaurants in rural Nepal and its capital city Kathmandu.

3 Normally Nepali people have lunch at around 10:00 am. We call it Khana. We have Khaja (snacks) at around 3:00 pm. Khaja is the part of meal in the afternoon before dinner. It is lighter than the Khana (lunch and dinner).

4 A head of the village in a traditional society.

5 A hen-packed male.

6 It is locally called Yarcha Gumba. Its scientific name is Ophiocordycepssinensis. But people call it Chyau (Mushroom) in their everyday life conversation.

\section{References}

District Education Office. (2010). District education plan 2067/68- 2071-72. Jumla, Nepal: Author.

Clandinin, D. J., \& Connelly, F. M. (2000). Narrative inquiry: Experience and story in qualitative research. San Francisco, CA: Jossey-Bass.

Freeman, M. (2007). Autobiographical understanding and narrative inquiry. In D. J. Clandinin (Ed.), Handbook of narrative inquiry: Mapping a methodology (pp. 120-146). Thousand Oaks, CA: Sage.

Garmezy, N., \& Masten, A. S. (1991). The protective role of competence indicators in children at risk. In E. M. Cummings, A. L. Greene, \& K. H. Karraker (Eds.), Life-span developmental psychology: Perspectives on stress and coping (pp. 151-74). Mahwah, NJ: Lawrence Erlbaum.

Liborio, R. M. C., \& Ungar, M. (2013). Resilience as protagonism: Interpersonal relationships, cultural practices, and personal agency among working adolescents in Brazil. Journal of Youth Studies, 17(5), 682-696. doi:10.1080/1 
106 S. Gautam

3676261.2013 .834313

Reyes, J. (2013). What matters most for students in contexts of adversity: A framework paper, Educational resilience approaches program. Washington, DC: World Bank.

Trahar, S. (2008a). It starts with once upon a time... Compare: A Journal of Comparative and International Education, 38(3), 259-266. doi:10.1080/03057920802066519

Trahar, S. (2008b). Review of the book Using narrative inquiry as a research methods: An Introduction to using critical event narrative analysis in research on learning and teaching, by Leonard Webster and Patricie Mertova. Compare: A Journal of Comparative and International Education, 38(3), 367-368.

Ungar, M. (2004). A constructionist discourse on resilience multiple contexts, multiple realities among at-risk children and youth. Youth Society, 35(3), 341365.

Ungar, M. (2011). Social ecology of resilience: A handbook of theory and practice. New York, NY: Springer.

Webster, L., \& Mertova, P. (2007). Using narrative inquiry as a research method: An introduction to using critical event narrative analysis in research on learning and teaching. New York, NY: Routledge.

Werner, E. E., \& Smith, R. S. (1992). Overcoming the odds: High risk children from birth to adulthood. Ithaca, NY: Cornell University Press. 